\title{
NATIONAL SMILE MONTH CAMPAIGN GATHERS PACE
}

This month sees the start of National Smile Month UK. Lead by independent oral health charity the British Dental Health Foundation (BDHF), this year's campaign slogan, 'Teeth4Life', highlights the importance of looking after your teeth and maintaining them for life, also stressing that a healthy diet can improve the quality of your life.

The campaign will run between May 16 and June 16 and will encourage dentists to promote their practices, and patients to maintain regular dental visits. BDHF Chief Executive, Dr Nigel Carter, believes this year's 'Teeth4Life' campaign will get the nation talking about the importance of good oral health and he anticipates yet another successful campaign.

To assist the public in maintaining good oral health, the Foundation will run three key messages throughout the campaign. They are to brush teeth twice daily with fluoride toothpaste, to visit the dentist regularly, as often as they recommend and to cut down on how often you eat sugary snacks or drinks.

Another vital aspect of the campaign has been the National Smile Month Survey, which investigates the dental habits

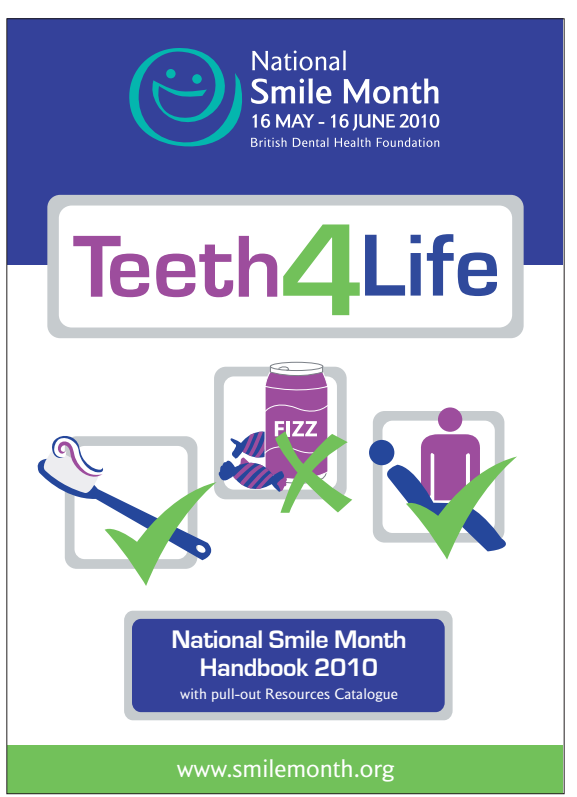

National Smile Month handbook

and oral health knowledge of over 1,000 people in the UK.

Dr Nigel Carter said, 'When the first ever Smile campaign was launched more than 35 years ago, one in three people over the age of 16 had no teeth at all. Now that is something you really have to think about twice to appreciate. Fortunately, these days the situation is a much happier one. Most of us expect to keep our teeth for life and indeed do so. National Smile Month is all about educating people on how to make the best of their smile.'

Daniel Davis, who was recently elected as the 19th President of the British Dental Health Foundation, said that this year's campaign was an important stepping stone in raising the Foundation's profile. He was elected at the Foundation's Annual General Meeting, held recently at the Royal Society for the Promotion of Health in London. Daniel, Operations Director at Plandent Limited, follows in his father John Davis's footsteps, who was instrumental in setting up the Foundation in 1971 and became the first non-dentist Chairman in 1989.

If you are interested in organising an event for National Smile Month you can find information, a copy of the 2010 guide, event ideas, downloadable materials, sponsorship forms and a chance to register your activity at www.smilemonth.org. In addition, you can enter your National Smile Month event into the annual Dental Awards 'Best National Smile Month event' category. For more details, please contact the Foundation at pr@dentalhealth.org.

\section{CALL FOR DENTISTS WITH OLYMPIC SPIRIT}

The World Medical and Health Games are calling for sporty health professionals to compete in various sports in a fun and friendly atmosphere.

Created in 1978, the Medigames now welcome more than 2,000 health professionals from 40 countries every year. Following events held in St Tropez in
France, Garmisch-Partenkirchen in Germany, Alicante in Spain and Agadir in Morocco, this year's 31st event will take place in Porec, Croatia.

The eight day event includes 22 sports in an Olympic spirit such as athletics, badminton, cycling, fencing, football, golf, judo, swimming, squash, tennis, table tennis, Olympic shooting, clay pigeon shooting, triathlon, sailing, volley-Ball, and mountain biking.

There are five age categories, an international sports competition with a professional organisation, an international Sports Medicine Symposium, a nations parade, followed by a spectacular opening ceremony, and closing ceremony.

For details visit www.medigames.com. 